\title{
Systems and rates of aerial application of fungicides in irrigated rice
}

\author{
Tânia Bayer ${ }^{1}$, Milton F. Cabezas-Guerrero², Casimiro D. Gadanha Junior ${ }^{3}$ \& Alci E. Loeck ${ }^{4}$ \\ ${ }^{1}$ Universidade Federal de Pelotas/Programa de Pós-Graduação em Fitossanidade. Pelotas, RS. E-mail: tania_bayer@hotmail.com (Corresponding author) \\ ${ }^{2}$ Universidad Tecnica Estatal de Quevedo/Campus “Ingeniero Manuel Agustín Haz Álvarez". Quevedo, Los Ríos, Ecuador. E-mail: fernando_cabezas@outlook.com \\ ${ }^{3}$ Universidade de São Paulo/Escola Superior de Agricultura "Luiz de Queiroz"/Departamento de Engenharia de Biossistemas. Piracicaba, SP. E-mail: \\ cdgadanh@usp.br \\ ${ }^{4}$ Universidade Federal de Pelotas/Departamento de Fitossanidade. Pelotas, RS. E-mail: alcienimar@yahoo.com.br
}

\section{Key words:}

Stol ${ }^{\circledast}$ nozzle

Travicar $^{\circledast}$ nozzle

aerial application

\begin{abstract}
A B S T R A C T
The present research studied the performance of flat-fan and hollow-cone nozzles, with application rates of 20 and $30 \mathrm{~L} \mathrm{ha}^{-1}$, and rotary disc atomizer with application rates of 10 and $15 \mathrm{~L} \mathrm{ha}^{-1}$. The test was conducted with a fungicide spray tank composed of Azoxystrobin + Difenoconazole, in which the density and penetration of droplets into the canopy were evaluated using a water-sensitive paper and the distribution of the active ingredients in the plant was evaluated through the chromatographic analysis. Higher application rates resulted in higher droplet density in the upper stratum of plants. In all treatments, the penetration of the droplets was $26 \%$ into the middle stratum and $23 \%$ into the lower stratum, in relation to the top of the crop, resulting in an average $25 \%$ penetration of droplets into the leaf canopy. The active ingredients were distributed in greater quantity in the upper stratum of the plant. For the same weight, the upper part of the 'Puitá Inta CL' rice cultivar has a leaf area 6.4 times larger than the lower part. It was concluded that higher application rate leads to higher droplet density in the upper stratum of the leaf canopy and that all systems and application rates promoted similar penetration of droplets into the canopy.
\end{abstract}

\section{Palavras-chave:}

bico Stol ${ }^{\circledast}$

bico Travicar ${ }^{\circledast}$

aeroaplicação

\section{Sistemas e taxas de aplicação aérea de fungicidas em arroz irrigado}

\section{R E S U M O}

Estudou-se o desempenho dos bicos defletor e cônico, com taxas de aplicação de 20 e $30 \mathrm{~L} \mathrm{ha}^{-1}$, e atomizador rotativo de discos com volumes de 10 e $15 \mathrm{~L} \mathrm{ha}^{-1}$. O ensaio foi realizado com uma calda de fungicida composta da Azoxistrobina + Difenoconazol (Priori + Score ${ }^{\oplus}$ ), onde se avaliou a densidade e penetração de gotas no dossel das plantas com auxílio de papel hidrossensível e a distribuição dos princípios ativos na planta através da análise cromatográfica. Em todos os tratamentos a penetração das gotas no estrato médio foi $26 \%$ e no inferior $23 \%$ em relação ao topo da cultura, resultando numa média de $25 \%$ de penetração de gotas no dossel foliar. Os princípios ativos distribuíram-se em maior quantidade no estrato superior da planta, em estádio R3. Para o mesmo peso, à parte superior da cultivar de arroz Puitá Inta CL possui área foliar 6,4 vezes maior em relação a parte inferior. Conclui-se que o maior volume de aplicação proporciona maior densidade de gotas no estrato superior foliar e que todos os sistemas e volumes de aplicação promoveram similar penetração de gotas no dossel. 


\section{INTRODUCTION}

Application technology seeks adequate deposition of phytosanitary products in adequate amounts on the target, at the opportune moment, with minimum loss and maximum safety to humans and environment (Boller, 2007).

Aerial application of pesticides is a valuable tool in agriculture, if based on well-defined technical criteria, such as the correct choice of flying height and spray volume used, type of target to be reached, ideal moment for spraying, experience of the applier, water quality, most adequate pesticide, application equipment, climatic conditions and use of agricultural adjuvants. Hence, these criteria become fundamental for the operation to occur efficiently, reducing the risk of drift and environmental impact (Cunha et al., 2011).

Aerial spraying in the irrigated rice crop is necessary because of the difficult trafficability of terrestrial machines and allows to apply pesticides at the correct moment and under more favorable climatic conditions (Boller et al., 2008).

This management allows to control fungal diseases in irrigated rice crops in Southern Brazil, which may compromise yield and quality of harvested grains. Damages to the yield caused by leaf spots may be up to 50\% (Celmer et al., 2007).

Another important factor in crop management is the reduction in the spray application rate associated with the application cost. This can be the main component in the operating performance in many crops (Román et al., 2009), which makes it important to know the relationship between droplet size, penetration into the canopy, distribution uniformity and effectiveness of deposition (Balan et al., 2008).

Therefore, using water-sensitive papers is a practical method to analyze application quality in the field. However, there may be some distortions, especially in situations in which droplets are small, as in the case of aerial applications (Antuniassi, 2009). According to Prestes et al. (2009), chromatography is the most accurate form to evaluate the quantity of active ingredient deposited on plants.

This study aimed to evaluate different systems and rates of aerial application.

\section{Material AND Methods}

The experiment was installed in a commercial production area in the municipality of Camaquã, Rio Grande do Sul, Brazil ( $30^{\circ} 56^{\prime} 59^{\prime \prime} \mathrm{S} ; 51^{\circ} 45^{\prime} 22.29^{\prime \prime} \mathrm{W} ; 17 \mathrm{~m}$ ). The experimental area comprised 50.4 hectares, divided into six plots of $210 \times 400 \mathrm{~m}$. Each plot received 14 applications with $15-\mathrm{m}$-wide strips. The area was delimited with a portable GPS device (Satloc M3). The rice (Oryza sativa) cultivar 'Puitá Inta CL' was used, at spacing of $0.20 \mathrm{~m}$ between rows and density of 65 seeds per linear meter. The experiment was carried out with six treatments and five replicates. All replicates were collected within the plot, taking care to leave a border to avoid drift or overlapping of treatments. Wind speed remained on average at $23 \mathrm{~km} \mathrm{~h}^{-1}$, with aligned wind.

Application was performed at the moment of panicle emergence, R3 growth stage (Counce et al., 2000) and the mixture of fungicides consisted in the active ingredients
Azoxystrobin $250 \mathrm{~g}+$ Difenoconazole $250 \mathrm{~g}$, commercialized with the name of Priori + Score at dose of $0.4+0.15 \mathrm{~L} \mathrm{ha}^{-1}$, plus the adjuvant Nimbus $0.5 \mathrm{~L} \mathrm{ha}^{-1}$, mixed with the vegetable oil Agróleo $0.5 \mathrm{~L} \mathrm{ha}^{-1}$ when the rotary disc atomizer was used, because the BVO' (low oil volume) system required only mixture with addition of oil.

The percentages of Agróleo vegetable oil for the volumes $30,20,15$ and $10 \mathrm{~L} \mathrm{ha}^{-1}$ are respectively: 1.6, 2.5, 3.3 and 5\%. The evaluated systems were: Stol flat-fan nozzle $20 \mathrm{~L} \mathrm{ha}^{-1}$ (BL 20) and $30 \mathrm{~L} \mathrm{ha}^{-1}$ (BL 30); Travicar hollow-cone nozzle, with volume of $20 \mathrm{~L} \mathrm{ha}^{-1}$ (BC 20) and $30 \mathrm{~L} \mathrm{ha}^{-1}$ (BC 30), and Turboaero rotary disc atomizer, with volumes of $10 \mathrm{~L} \mathrm{ha}^{-1}$ (ATM 10) and $15 \mathrm{~L} \mathrm{ha}^{-1}$ (ATM 15). Applications were made using the Cessna Ag Truck aircraft, model A188B, equipped with Interflow flow meter. Flying height was $3 \mathrm{~m}$ with the flat-fan and hollow-cone nozzles and $4 \mathrm{~m}$ with the rotary disc atomizers. 38 flat-fan nozzles, 42 hollow-cone nozzles and 10 rotary atomizers were used per bar. Angles for hollow-cone nozzles were regulated for $90^{\circ}$ in relation to the flying line; for atomizers, the regulation was 3.5 in the blades, and for flat-fan nozzles, the angle was $90^{\circ}$. Pressures were equal to $207 \mathrm{kPa}$ for flat-fan and hollow-cone nozzles, and $172 \mathrm{kPa}$ for rotary disc atomizers, with aircraft speed of $180 \mathrm{~km} \mathrm{~h}^{-1}$.

Deposition and penetration of droplets into the canopy were evaluated using water-sensitive paper, which was placed on 1-m-high posts divided into three levels of $30 \mathrm{~cm}$, a height that is consistent with the plant growth stage. The posts were arranged in the plots, one per replicate, totaling five posts per treatment. Water-sensitive papers were horizontally fixed with a rubber tie and collected immediately after spraying, individually wrapped in aluminum paper and sent to the company Agrotec for analysis.

Droplet density was obtained by capturing the image of the cards with a scanner, on $1-\mathrm{cm}^{2}$ surfaces, with subsequent analysis of the digitalized image using the software Agroscan (AGROTEC, 2014). This software allows to evaluate droplet size with a 600-DPI resolution. Penetration (\%) was calculated based on droplet density obtained in the upper third of the plant, which represented $100 \%$. Hence, droplet penetration represents the relationship between the density of droplets from the middle and lower thirds, compared with the upper third.

Abi Saab et al. (2002) suggest that the best form to evaluate and quantify the deposition of mixtures is to analyze parts of the plant.

Samples for chromatographic analysis were randomly collected within the plots, and plants were cut in half to separate the upper and lower parts. The samples were properly wrapped in aluminum paper, placed in plastic bags, preserved with dry ice and transported to the LARP (Pesticide Residue Analysis Laboratory, of the Federal University of Santa Maria), where they were maintained at $-18{ }^{\circ} \mathrm{C}$. The samples were analyzed by Gas Chromatography coupled with Mass Spectrometry, according to the modified QuEChErS methodology (Lehotay et al., 2005), which extracts the content of $10 \mathrm{~g}$ of sample.

Leaf area was determined by randomly collecting 16 representative plants within the experimental area. Plants and soil were placed in $5 \mathrm{~L}$ plastic buckets containing water to maintain them under normal vegetative conditions 
until the moment of measurement. Plants were cut in half, resulting in upper and lower parts. Leaf area of $10 \mathrm{~g}$ of both parts was measured, following the procedure adopted in the chromatographic analysis of the samples. Measurements were taken using an area meter (LI-COR, model LI 3100C) and the values corresponded to the abaxial and adaxial sum of leaves and stems.

The experiment was conducted in completely randomized design, with six treatments and five replicates. Residual normality and homoscedasticity were analyzed with the PROC UNIVARIATE procedure of the SAS program (SAS Institute, 2002). Data of droplet penetration and chromatography were transformed using the formula $\sqrt{\mathrm{x}}+0.5$, for not meeting normality and homoscedasticity assumptions. The data were subjected to analysis of variance and means were compared by Tukey $(\mathrm{p}<0.05)$, when significant effect was observed in the $\mathrm{F}$ test, using the PROC ANOVA procedure of the SAS program (SAS Institute, 2002).

Differences between systems and volumes of application were determined through the Scheffés contrast method, at 0.05 significance level. The analyzed contrasts were: C1 (flat-fan nozzle with volume $20 \mathrm{~L} \mathrm{ha}^{-1}+$ flat-fan nozzle with volume $30 \mathrm{~L} \mathrm{ha}^{-1}$ vs hollow-cone hydraulic nozzle with volume $20 \mathrm{~L} \mathrm{ha}^{-1}+$ hollow-cone hydraulic nozzle with volume $30 \mathrm{~L} \mathrm{ha}^{-1}$ ); C2 (flatfan nozzle with volume $20 \mathrm{~L} \mathrm{ha}^{-1}+$ flat-fan nozzle with volume $30 \mathrm{~L} \mathrm{ha}^{-1}$ vs rotary disc atomizer with volume of $10 \mathrm{~L} \mathrm{ha}^{-1}+$ rotary disc atomizer with volume of $15 \mathrm{~L} \mathrm{ha}^{-1}$ ); C3 (hollowcone hydraulic nozzle with volume $20 \mathrm{~L} \mathrm{ha}^{-1}+$ hollow-cone hydraulic nozzle with volume $30 \mathrm{~L} \mathrm{ha}^{-1} \mathrm{vs}$ rotary disc atomizer with volume of $10 \mathrm{~L} \mathrm{ha}^{-1}+$ rotary disc atomizer with volume of $15 \mathrm{~L} \mathrm{ha}^{-1}$ ), and for application rates the following contrast was tested: C4 (flat-fan nozzle with volume of $30 \mathrm{~L} \mathrm{ha}^{-1}+$ hollowcone hydraulic nozzle with volume of $30 \mathrm{~L} \mathrm{ha}^{-1}+$ rotary disc atomizer with volume of $15 \mathrm{~L} \mathrm{ha}^{-1}$ vs flat-fan nozzle with volume of $20 \mathrm{~L} \mathrm{ha}^{-1}+$ hollow-cone hydraulic nozzle with volume of $20 \mathrm{~L} \mathrm{ha}^{-1}+$ rotary disc atomizer with volume of $\left.10 \mathrm{~L} \mathrm{ha}^{-1}\right)$.

\section{Results AND Discussion}

Droplet density in the upper third differed between systems and volumes tested, and there were variations from 74.78 to 93.74 droplets $\mathrm{cm}^{-2}$ between hollow-cone nozzle with volumes of 20 and $30 \mathrm{~L} \mathrm{ha}^{-1}$ and flat-fan nozzle with volume of $30 \mathrm{~L} \mathrm{ha}^{-1}$ (Table 1). The results confirmed the relationship between the increase in spray volume and droplet density, found by Schröder \& Loeck (2006) in the rice crop to control weeds.

Higher number of droplets in the upper stratum was achieved with systems that produced more heterogeneous droplets and greater application volume, as found by Reis et al., (2010), who investigated aerial application in the soybean crop and observed lower coverage of droplets in the middle third, compared with the upper third. Martini et al. (2016) compared hollow-cone and electrostatic nozzles and found higher densities in the treatment with hollow-cone nozzles and application volumes of 15 and $20 \mathrm{~L} \mathrm{ha}^{-1}$.

All treatments with application rates from $20 \mathrm{~L} \mathrm{ha}^{-1}$ on led to the minimum density established for treatment with
Table 1. Droplet density (droplet $\mathrm{cm}^{-2}$ ) and droplet penetration percentage in irrigated rice plants, cultivar 'Puitá Inta $\mathrm{CL}^{\prime}$

\begin{tabular}{|c|c|c|c|c|c|}
\hline \multirow{2}{*}{ Treat. } & \multicolumn{3}{|c|}{ Droplet density } & \multicolumn{2}{|c|}{ Penetration $^{1}$} \\
\hline & Upper & Middle & Lower & Middle & Lower \\
\hline BL 20 & $54.34 b^{*}$ * & $15.66 \mathrm{a}$ & $13.93 \mathrm{a}$ & $32.53 \mathrm{a}$ & $31.38 \mathrm{a}$ \\
\hline BL 30 & $74.78 a b$ & $12.87 \mathrm{a}$ & $12.81 \mathrm{a}$ & $17.33 \mathrm{a}$ & $18.40 \mathrm{a}$ \\
\hline BC 20 & $76.12 \mathrm{ab}$ & $21.58 \mathrm{a}$ & $7.17 \mathrm{a}$ & $28.24 \mathrm{a}$ & $9.35 \mathrm{a}$ \\
\hline BC 30 & $93.74 \mathrm{a}$ & $16.25 \mathrm{a}$ & $13.79 \mathrm{a}$ & $18.66 \mathrm{a}$ & $15.98 \mathrm{a}$ \\
\hline ATM10 & $32.52 \mathrm{c}$ & $10.13 \mathrm{a}$ & $9.71 \mathrm{a}$ & $33.58 \mathrm{a}$ & $31.70 \mathrm{a}$ \\
\hline ATM 15 & 45.32 bc & $12.21 \mathrm{a}$ & $14.79 a$ & $27.14 \mathrm{a}$ & $29.08 \mathrm{a}$ \\
\hline$F$ value & $6.53^{\text {** }}$ & $2.05^{\mathrm{ns}}$ & $0.69^{\text {ns }}$ & $1.8^{\mathrm{ns}}$ & $2.18^{\mathrm{ns}}$ \\
\hline $\operatorname{Pr}>\mathrm{F}$ & 0.0006 & 0.1075 & 0.6344 & 0.1519 & 0.0897 \\
\hline CV (\%) & 31.60 & 42.56 & 66.21 & 13.36 & 16.07 \\
\hline
\end{tabular}

*Means followed by the same letters in the column do not differ by Tukey test $(p \geq 0.05)$ ${ }^{1}$ Density value relative to the upper third as $100 \%$, a reference to calculate the penetration into the middle and lower thirds. ${ }^{n}$ Values not significant by $\mathrm{F}$ test. ${ }^{*}$ Values significant by $\mathrm{F}$ test

fungicides, close to 50 droplets $\mathrm{cm}^{-2}$ (Ozeki \& Kunz, 1996). Cunha et al. (2010) found similar result for the number of droplets that reached the upper, middle and lower thirds of corn plants.

Cunha \& Carvalho (2005) obtained higher spray deposition on sensitive papers with application volume of $20 \mathrm{~L} \mathrm{ha}^{-1}$, compared with lower application rates. These results can be considered as similar to those found in the present study, since the highest volume used ( $30 \mathrm{~L} \mathrm{ha}^{-1}$ ), applied with hollow-cone nozzle, had higher deposition on the upper third of the canopy. Chaim (2009) demonstrated that the smaller the droplet, the higher its penetration into the lower strata of the crop.

There was no difference for droplet density and penetration in the middle and lower strata (Table 1), due to the higher droplet density in the upper part of the plants, which is caused by the greater exposure of the target to the spraying. Lower deposition of droplets on the lower canopy level is related to the greater volume of leaves in the upper canopy level, which compromises droplet penetration. All treatments led to penetration of $26 \%$ in the middle stratum and $23 \%$ in the lower stratum.

Chromatographic analysis quantified the deposition of products without the known limitations for water-sensitive cards (Table 2). The difference found between both active principles in the analysis is justified because the Azoxystrobin dose is approximately 2.66 times higher. Because of that, the active principles were analyzed independently, to determine the quantity of product and evidence the quality of the analysis.

Table 2. Chromatographic concentration analysis for Difenoconazole and Azoxystrobin, in the lower and upper strata of rice plants

\begin{tabular}{|c|c|c|c|c|}
\hline \multirow{2}{*}{ Treat. } & \multicolumn{2}{|c|}{ Upper stratum (mg kg-1) } & \multicolumn{2}{|c|}{ Lower stratum $\left(\mathrm{mg} \mathrm{kg}^{-1}\right)$} \\
\hline & Difenoconazole & Azoxystrobin & Difenoconazole & Azoxystrobin \\
\hline $\mathrm{BL} 20$ & $25.76 a^{*}$ & $78.94 \mathrm{a}$ & $1.42 \mathrm{a}$ & $4.02 \mathrm{a}$ \\
\hline BL 30 & $15.82 \mathrm{a}$ & $44.30 \mathrm{a}$ & $0.48 b$ & $1.36 \mathrm{ab}$ \\
\hline BC 20 & $17.62 \mathrm{a}$ & $77.26 \mathrm{a}$ & $0.64 a b$ & $1.38 \mathrm{ab}$ \\
\hline BC 30 & $31.98 \mathrm{a}$ & $90.68 \mathrm{a}$ & $1.20 a b$ & $2.36 \mathrm{ab}$ \\
\hline ATM 10 & $13.84 \mathrm{a}$ & $38.12 \mathrm{a}$ & $0.76 \mathrm{ab}$ & $1.34 \mathrm{~b}$ \\
\hline ATM 15 & $8.76 \mathrm{a}$ & $23.38 \mathrm{a}$ & $0.60 a b$ & $0.78 b$ \\
\hline F value & 2.49 & 2.55 & 3.7 & 3.99 \\
\hline $\operatorname{Pr}>\mathrm{F}$ & $0.0591^{\mathrm{ns}}$ & $0.0549^{\mathrm{ns}}$ & $0.0127^{* *}$ & $0.0089^{* *}$ \\
\hline CV (\%) & 63.15 & 35.17 & 51.17 & 26.53 \\
\hline
\end{tabular}

*Means followed by the same letters in the column do not differ by Tukey test $(p \geq 0.05)$ ${ }^{\text {ns }}$ Values not significant by $\mathrm{F}$ test. ${ }^{* *}$ Values significant by $\mathrm{F}$ test 
Table 3. Quantity of active ingredient of Azoxystrobin and Difenoconazole recovered by the chromatographic analysis in the lower and upper thirds of the plant obtained from $10 \mathrm{~g}$ of sample and the corrected values for leaf area equivalence

\begin{tabular}{|c|c|c|c|c|c|}
\hline \multirow{2}{*}{ Fungicide } & \multirow{2}{*}{ No. of samples } & \multicolumn{2}{|c|}{ Lower mean (ppm) } & \multirow{2}{*}{$\begin{array}{l}\text { Upper mean } \\
\text { (ppm) }\end{array}$} & \multirow{2}{*}{$\begin{array}{c}\text { Penetration } \\
(\%)\end{array}$} \\
\hline & & Obtained & Corrected (6.4x) & & \\
\hline Azoxystrobin & 28 & 1.89 & 12.20 & 51.13 & 24 \\
\hline Difenoconazole & 30 & 0.85 & 5.44 & 18.96 & 28 \\
\hline
\end{tabular}

High coefficients of variation may be due to the experimental design itself, especially to the distance between spraying and target, effect of wind gusts on droplet distribution and plot size. The experiment was conducted in a considerably large area, due to the use of agricultural aircraft to apply the treatments, which reflects the actual aerial application but compromises the control of the above-mentioned factors.

The highest quantities of Azoxystrobin were obtained with flat-fan nozzle and hydraulic hollow-cone nozzle in the lower stratum. This difference may be associated with the spray volume of the treatments with atomizer, 10 and $15 \mathrm{~L} \mathrm{ha}^{-1}$. Bayer et al. (2011) found different results evaluating rice plants, cultivar 'Qualimax 1', through the same analysis. The BVO' system, at application rates of 15 and $6 \mathrm{~L} \mathrm{ha}^{-1}$, led to highest depositions on the lower canopy level, being the best treatments.

Chromatographic analysis revealed small quantity of product in the lower stratum (Table 2), not consistent with the density of droplets collected in the water-sensitive cards (Table 1), because the samples were processed according to the modified QuEChErS methodology (Lehotay et al., 2005), which is based on the extraction of $10 \mathrm{~g}$ of sample. With this weight, the samples had average area of $1055.78 \mathrm{~cm}^{2}$ in the upper stratum and $165.01 \mathrm{~cm}^{2}$ in the lower stratum. In this context, it was noted that the upper part has an area 6.4 times larger; thus, correction was made using this value as a correction factor (Table 3 ).

Thus, to obtain the equivalence of leaf area, it is necessary to use 6.4 times more of weight of the upper part for the cultivar 'Puitá Inta CL', i.e., $64 \mathrm{~g}$ of the lower part.

The analysis between proportion, droplet deposition and fungicide quantity found at both canopy levels demonstrates that the mean is close to the ratio between both strata, revealing consistency with the chromatographic results and droplet density (Table 4 ).
Table 4. Proportions between droplet density and quantity of Azoxystrobin and Difenoconazole in the upper and lower strata of rice plants

\begin{tabular}{lccc}
\hline \multicolumn{1}{c}{ Parameter } & N & Mean & $\begin{array}{c}\text { Standard } \\
\text { error }\end{array}$ \\
\hline Azoxystrobin upper vs lower & 28 & $28.33 \mathrm{a}^{*}$ & 7.12 \\
\hline Difenoconazole upper vs lower & 30 & $23.01 \mathrm{a}$ & 7.07 \\
\hline $\begin{array}{l}\text { Droplet density upper vs lower } \\
\text { Azoxystrobin upp. vs Azoxystrobin }\end{array}$ & 30 & $5.59 \mathrm{~b}$ & 2.87 \\
low. corrected $^{1}$ & 28 & $4.42 \mathrm{~b}$ & 1.11 \\
Difenoconazole upp. vs Difenoconazole $^{\text {low. corrected }}{ }^{1}$ & 30 & $3.59 \mathrm{~b}$ & 1.10 \\
\hline F $>$ p & & $3.5 \times 10^{-10}$ & \\
\hline
\end{tabular}

${ }^{1}$ Value resulting from the division of the original value by 6.4 (mean proportion between upper and lower leaf area). * * Means followed by the same letters in the column do not differ by Tukey test $(p \geq 0.05)$

Although the water-sensitive paper records the spray volume and the chromatographic analysis records the active ingredient, both evaluations showed similar results. Watersensitive papers indicated that there was, on average, $26 \%$ of penetration into the middle stratum and $23 \%$ into the lower stratum (Table 1). The percentage between both chemical compounds in the corrected upper and lower strata was on average $26 \%$, results that confirm those obtained with watersensitive paper and chromatography.

There was no difference for droplet density in the lower, middle and upper strata, except for the contrasts evaluating $\mathrm{BC}^{*} \mathrm{ATM}(\mathrm{p}<0.05)$, indicating that flat-fan and hollow-cone nozzles led to higher droplet density in the upper stratum (Table 5).

Bayer et al. (2011) found higher droplet density with greater spray volume, in different strata analyzed, when different systems and application rates were evaluated in the irrigated rice crop. The results indicate greater penetration of droplets with rotary atomizers, a fact related to the production of small droplets and addition of adjuvants, which promote longer

Table 5. Orthogonal contrasts for droplet density in the different treatments

\begin{tabular}{|c|c|c|c|c|c|}
\hline \multirow{2}{*}{ Contrast } & \multirow{2}{*}{ Estimate } & \multirow{2}{*}{ Standard error } & \multirow{2}{*}{ Critical value $(0.05)$} & \multicolumn{2}{|c|}{ CI 95\% } \\
\hline & & & & Lower & Upper \\
\hline \multicolumn{6}{|c|}{ Droplet density (droplet $\mathrm{cm}^{-2}$ ) in the upper stratum } \\
\hline$B L \times B C$ & $-40.74^{\text {NS }}$ & 17.75 & 64.25 & -104.99 & 23.51 \\
\hline BL $x$ ATM & $51.28^{\mathrm{NS}}$ & 17.75 & 64.25 & -12.97 & 115.53 \\
\hline$B C \times A T M$ & $92.02^{\mathrm{Sig}}$ & 17.75 & 64.25 & 27.77 & 156.27 \\
\hline Higher x Lower volume & $50.86^{\mathrm{NS}}$ & 21.74 & 78.69 & -27.83 & 129.55 \\
\hline \multicolumn{6}{|c|}{ Droplet density (droplet $\mathrm{cm}^{-2}$ ) in the middle stratum } \\
\hline$B L \times B C$ & $-9.30^{\mathrm{NS}}$ & 5.63 & 20.37 & -29.67 & 11.06 \\
\hline BL $x$ ATM & $6.20^{\mathrm{NS}}$ & 5.63 & 20.37 & -14.17 & 26.56 \\
\hline BC $\times$ ATM & $15.50^{\mathrm{NS}}$ & 5.63 & 20.37 & -4.86 & 35.87 \\
\hline Higher x Lower volume & $-6.04^{\mathrm{NS}}$ & 6.89 & 24.94 & -30.98 & 18.91 \\
\hline \multicolumn{6}{|c|}{ Droplet density (droplet $\mathrm{cm}^{-2}$ ) in the lower stratum } \\
\hline$B L \times B C$ & $5.78^{\mathrm{NS}}$ & 7.13 & 25.79 & -20.01 & 31.57 \\
\hline BL x ATM & $2.24^{\mathrm{NS}}$ & 7.13 & 25.79 & -23.55 & 28.03 \\
\hline BC $\times$ ATM & $-3.54^{\mathrm{NS}}$ & 7.13 & 25.79 & -29.33 & 22.25 \\
\hline Higher x Lower volume & $10.58^{\mathrm{NS}}$ & 8.73 & 31.59 & -21.00 & 42.17 \\
\hline
\end{tabular}

NS - Not significant according to the Scheffé's contrast analysis $(p \geq 0.05)$ 
useful life, increasing the chances of reaching the target. The same authors, evaluating contrasts and comparing application rates with droplet density, cite that the data follow the same trend found for penetration into the canopy: higher droplet densities were generated using larger spray volumes per hectare, in both strata analyzed.

Oliveira et al. (2011) found similar values in the deposition of droplets for hydraulic nozzles (30 and $40 \mathrm{~L} \mathrm{ha}^{-1}$ ) and Micronair atomizer (10 and $20 \mathrm{~L} \mathrm{ha}^{-1}$ ). These authors comment the possibility of using reduced application rates and the applicability of hydraulic nozzles for this type of spraying.

Variance analysis did not point to relationship $(\mathrm{p}=0.63)$ between treatments for droplet density in the lower stratum. After comparing each one of the contrasts, there were no differences ( $p \geq 0.05)$ between systems and volumes, because the estimated value of each one of the contrasts did not exceed its respective critical value.

Atomizers generate smaller droplets and increase the coverage and penetration into the canopy, but flat-fan nozzle and hollow-cone nozzles reduce drift due to the larger size of the droplets. Hence, in all treatments there was no difference for the penetration of droplets, indicating that the choice on the spraying nozzles in irrigated rice will be at the producer's discretion.

\section{Conclusions}

1. Higher application rate promotes higher density of droplets in the upper stratum of the leaf canopy.

2. Hollow-cone nozzles, flat-fan nozzles and rotary atomizers lead to similar penetration of droplets into the lower and middle thirds of the canopy.

3. Hollow-cone nozzles, flat-fan nozzles and rotary atomizers can be used in aerial application of fungicides in irrigated rice.

\section{Literature Cited}

Abi Saab, O. J. G.; Antuniassi, U. R.; Fonseca, I. C. B.; Genta, W.; Batistela, M. Efeito do tamanho de gota e volume de aplicação na deposição de agrotóxicos em folhas de videira. Semina: Ciências Agrárias, v.23, p.66-68, 2002.

AGROTEC - Agrotec Tecnologia Agrícola e Industrial Ltda. Agroscan. Available in: <http://www.agrotec.etc.br >. Access in: 20 Jun. 2014.

Antuniassi, U. R. Conceitos básicos da tecnologia de aplicação de defensivos na cultura da soja. Boletim de Pesquisa da Soja, v.13, p.299-316, 2009.

Balan, M. G.; Abi Saab, O. J. G.; Silva, C. G. da; Rio, A. do. Deposição da calda pulverizada por três pontas de pulverização sob diferentes condições meteorológicas. Semina: Ciências Agrárias, v.29, p.293298, 2008. https://doi.org/10.5433/1679-0359.2008v29n2p293

Bayer, T.; Costa, I. F. D.; Lenz, G.; Zemolin, C.; Marques, L. N.; Stefanelo, M. S. Equipamentos de pulverização aérea e taxas de aplicação de fungicida na cultura de arroz irrigado. Revista Brasileira Engenharia Agrícola Ambiental, v.15, p.192-198, 2011. https://doi.org/10.1590/S1415-43662011000200007

Boller, W. Resposta da tecnologia de aplicação de defensivos em relação à concepção atmosférica visando o controle de doenças de plantas. Summa Phytopathologica, v.33, p.113-116, 2007.
Boller, W.; Hoffmann, L. L.; Forcelini, C. A.; Casa, R. T. Tecnologia de aplicação de fungicidas - Parte II. Revisão Anual de Patologia de Plantas, v.16, p.85-132, 2008.

Celmer, A.; Madalosso, M. G.; Debortoli, M. P.; Navarini, L.; Balardin, R. S. Controle químico de doenças foliares na cultura do arroz irrigado. Pesquisa Agropecuária Brasileira, v.42, p.901-904, 2007. https://doi.org/10.1590/S0100-204X2007000600019

Chaim, A. Manual de tecnologia de aplicação de agrotóxicos. Brasília: Embrapa Informação Tecnológica, 2009. p.15-37.

Counce, P. A.; Keisling, T. C.; Mitchell, A. J. A uniform, objective, and adaptative system for expressing rice development. Crop Science, v.40, p.436443, 2000. https://doi.org/10.2135/cropsci2000.402436x

Cunha, J. P. A. R. da; Carvalho, W. P. A. de. Distribuição volumétrica de aplicações aéreas de agrotóxicos utilizando adjuvantes. Engenharia na Agricultura, v.13, p.130-135, 2005.

Cunha, J. P. A. R. da; Carvalho, W. P. A. de. Tecnología de aplicación de agroquímicos por vía aérea. In: Magdalena, J. C.; Castillo, B. H.; Di Prinzio, A.; Homer, I. B; Villalba, J. Tecnología de aplicación de agroquímicos. 2010, p.157-168.

Cunha, J. P. A. R. da; Farnese, A. C.; Olivet, J. J.; Vilalba, J. Deposição de calda pulverizada na cultura da soja promovida pela aplicação aérea e terrestre. Engenharia Agrícola, v.31, p.343-351.2011. https:// doi.org/10.1590/S0100-69162011000200014

Lehotay, Steven J.; Maštovská, Kateřina; Lightfield, Alan R., Use of buffering and other means to improve results of problematic pesticides in a fast and easy method for residue analysis of fruits and vegetables. A. R. Journal of AOAC International, v.88, p.615629, 2005.

Martini, A. T.; Avila, L. A. C. de; Camargo, E. R.; Helgueira, D. B.; Bastiani, M. O.; Loeck, A. E. Pesticide drift from aircraft applications with conical nozzles and electrostatic system. Ciência Rural, v.46, p.1678-1682, 2016. https://doi.org/10.1590/0103-8478cr20151386

Oliveira, V. A. B. de; Oliveira, G. M. de; Giglioti, E. A.; Igarashi, W. T.; Abi Saad, O. J. G. Desempenho de bicos rotativos e hidráulicos na aplicação aérea de fungicidas em cana-de-açúcar. Revista Brasileira de Tecnologia Aplicada nas Ciências Agrárias, v.4, p.111-122, 2011.

Ozeki, Y.; Kunz, R. P. Tecnologia de aplicação aérea: aspectos práticos. In: Curso e atualização: Tecnologia e segurança na aplicação de produtos fitossanitários, 1996, Santa Maria, RS. Santa Maria: UFSM / Sociedade de Agronomia de Santa Maria, 1996. p.65-78.

Prestes, O. D.; Friggi, C. A.; Adaime, M. B.; Zanella, R. QuEChERS Um método moderno de preparo de amostra para determinação multirresíduo de pesticidas em alimentos por métodos cromatográficos acoplados à espectrometria de massas. Química Nova, v.32, p.1620-1634, 2009.

Reis, E. F. dos; Queiroz, D. M. de; Cunha, J. P. A. R. da; Alves, S. M. F. Qualidade da aplicação aérea líquida com uma aeronave agrícola experimental na cultura da soja. Engenharia Agrícola, v.30, p.958966, 2010. https://doi.org/10.1590/S0100-40422009000600046

Román, R. A. A.; Cortez, J. W.; Ferreira, M. C.; Oliveira, J. R. G. Cobertura da cultura da soja pela calda fungicida em função de pontas de pulverização e volumes de aplicação. Scientia Agraria, v.10, p.223-232, 2009. https://doi.org/10.5380/rsa.v10i3.14529

SAS. Statistical Analysis System (Release 8.1). Cary: The SAS Institute. 2002.

Schröder, E. P.; Loeck, A. E. Avaliação do sistema de pulverização eletrostática aérea na redução do volume de calda e dosagem do herbicida glifosate. Revista Brasileira de Agrociência, v.12, p.319$323,2006$. 